\title{
Support for childlessness: has anything changed between 2008 and 2015?
}

\section{Susan Quilliam}

Freelance Writer, Broadcaster, Consultant and Trainer, Cambridge, UK

\section{Correspondence to} Ms Susan Quilliam; susan@susanquilliam.com

Accepted 16 August 2015

\section{CrossMark}

To cite: Quilliam S. J Fam Plann Reprod Health Care 2015:41:306-308.

\section{BACKGROUND}

2015 has seen a 65-year-old German mother with 13 children expecting quadruplets, a media storm over the testing of new reproductive techniques on actual human pregnancies, and the autobiography of the first test-tube baby, Louise Brown. In such a year, it seems pertinent for the Consumer Correspondent column to explore the issue of not being able to have a child.

This is not the first such exploration. It was in 2008 that this column first interviewed three women whose fertility was in question. ${ }^{1}$ Kate had become perimenopausal at the age of 36 years. Jane, in her mid-20s, had been diagnosed with polycystic ovary syndrome, making it uncertain that she could conceive. Maria had been told that her heart condition meant she would be unwise to give birth.

The 2008 article concluded that none of these women felt fully supported in facing their situation. Information was scarce, support for their attempts to be fully involved in their diagnosis was even scarcer and, in particular, acknowledgement of their emotions was almost non-existent. I ended the 2008 article by suggesting that health professionals might find those judgments "hard to hear ... but necessary".

Have things improved, especially around acknowledgement that infertility is an emotional issue and needs support? In search of answers, I have looked beyond the medical profession to the media for indications of increased awareness, public opinion for evidence of greater sympathy, and private and public health sectors to see whether more help is now available. I also returned to the original interviewees to see what the intervening years have been like for them; none has since had children and for two the issue remains unresolved. I also contacted two women for whom infertility has been an issue more recently: Harriet (who decided not to undergo fertility treatment) and Felicity [whose in vitro fertilisation (IVF) was unsuccessful].

\section{THE MEDIA}

I looked first at media coverage of infertility. There certainly seems to be more of it; most major UK media outlets had covered the issue in some form in the past 12 months, sometimes more than once. However, most of this coverage reflected a medical viewpoint, comprising alarm calls to women to conceive early in life, or focusing on the cost of treatment. Few focused on the psychological challenges and the need for emotional support, although some, usually firstperson, articles supported the choice to remain 'child-free'. My interviewees were aware of this increase in coverage: "I have noticed more about how not having children can be ... positive", observes Jane, adding, "I'm not sure if this is media fashion or a reflection of society".

There is also evidence of media dismissiveness of infertility as perhaps insufficiently newsworthy, or too pessimistic, a topic. Paula Coston, a campaigner for childless women, expressed disappointment in The Huffington Post that her extensive press releases about a party to celebrate the joys of 'otherhood' (rather than motherhood) resulted in only two journalists attending of the 60 invited. New interviewee Felicity experienced not just indifference but negativity, commenting that if "an article has been written by a women who is infertile and who has dared to speak out about how angry she feels ... there will always be someone who ... says 'shut up and stop wallowing, you bitter woman' ... [which leaves many women] isolated in their pain". 


\section{PUBLIC OPINION}

Other interviewees echoed Felicity's view that public opinion towards infertility is still not supportive. While most reported at least short-term sympathy from family and friends, Jane reflects that: "The vast majority of my female friends still seem to view 'married with children' as the standard happy state, with variations on that seen as non-optimal or a bit odd", while Maria reports that more than a few friends "asked, when hearing that my husband had left, whether my inability to conceive was the reason. That shook me".

Kate points out the irony that IVF's success, nowadays, means that "if you can't conceive, it is even harder [to be understood]". There seems to be a general presupposition that if one wants a child one can have a child, and this only adds to any sense that being childless is somehow undeserving of sympathy a 21st century take on the late 20th century prejudice that childlessness is self-centred.

Some of my interviewees commented negatively on the insistence in some fertility clinics on baby-making being seen as the optimal choice with not much information being offered on other alternatives such as adoption or fostering.

\section{COUNSELLING}

None of my original interviewees was offered counselling, though some have since sought it; Jane "had some sessions with a [Relate] counsellor to talk everything through; it was helpful". Felicity felt that the initial medical approach she experienced consisted too often of attempts to 'fix' her problem with medical solutions but with no accompanying "acknowledgement of the ... situation and the hurt I was feeling". However, when she was treated at Bourn Hall, the private infertility clinic founded by the clinicians originally responsible for Louise Brown's birth, she was offered excellent counselling, and said "it was that which helped me cope" with the pain of not bearing able to bear a child.

My own impression is that there has been increasing National Health Service (NHS) awareness of the need for support over the past 8 years. A straw poll I did of colleagues suggests that most general practitioners and practice nurses would at least advise counselling, though none offered it directly in their surgeries. But many clinical commissioning groups do offer support, and with the rise of cognitive behavioural therapy in the NHS this is likely to increase, albeit doubtless capped because of funding issues.

The private sector has more leeway. One private infertility clinic in Cambridgeshire, remarkably, offers 'unlimited' counselling to couples, a huge acknowledgement of the length of time it takes to recover from infertility issues. Jackie Stewart, one of a team of three British Infertility Counselling Association (BICA) qualified AMBICA counsellors working with the clinic comments: "Infertility can feel a very lonely journey. If treatment is unsuccessful there is a grieving process to go through which for some can be devastating. Support can help women and their partners find a way forward".

BICA itself continues to develop guidelines, offer training and accredit counsellors, as well as raising the profile of infertility counselling across the UK. As reported in the April 2015 issue of this Journal, ${ }^{2}$ BICA reports patient complaints of not being offered counselling, not being offered funded counselling, and having limits set on the number of sessions offered. Even more concerning, BICA says that its biggest challenge is to persuade "clinics and senior clinicians of the value of counselling".

\section{PEER SUPPORT}

The past 7 years have seen a rise in peer group programmes; many private IVF clinics now have them.

There are also several charities offering face-to-face groups and online chatrooms (Box 1 lists useful resources). Fertility Friends describes itself as "the leading infertility community in the UK" and includes a wide variety of patient-led forums not only on conception but also on adoption, fostering and coming to terms with the status quo. The Infertility Network has a dedicated division More to Life for the 'involuntarily childless', offering information, a support line, a regional network and a website resource of inspirational articles, images and quotations.

The new organisation in peer support is Gateway Women. The site, started by Jody Day, has as its foundation her personal story of childlessness, leading to a programme designed to help women come to terms with the issue and find life beyond. Her book, Rocking the Life Unexpected: 12 Weeks to Your Plan B for a Meaningful and Fulfilling Life Without Children,

Box 1 Resources and additional reading for childless patients

Patients who are 'childless by circumstance' - even if their diagnosis was a while ago - may benefit from the following resources:

Ageing Without Children - http://www.awoc.org

Fertility Friends - http://www.fertilityfriends.co.uk Gateway Women - http://gateway-women.com; resource section: http://gateway-women.com/resources/ Infertility Network UK - http://www.infertilitynetworkuk. com

More to Life - http://www.infertilitynetworkuk.com/more to_life; support line: +44 (0)121 3235025

Rocking the Life Unexpected: 12 Weeks to Your Plan B for a Meaningful and Fulfilling Life Without Children by Jody Day (Amazon Media) 
has an extensive resource section. Day is also involved in Ageing Without Children, which campaigns for those who suffer from the absence of offspring in later years.

\section{CONCLUSIONS}

Compared to 2008 , the situation is clearly brighter for those struggling with their fertility. Certainly there is more awareness. Certainly in terms of counselling and peer support there is more availability. And for all five of my interviewees - three past, two present there seems to have been a relatively happy ending.

Maria now feels that she has a "vocation to work [in her career] in a way I never had a vocation to be a mother". Jane comments that "when I compare my life to that of friends with children ... [it] doesn't feel like a disaster". Kate says that "I am very much part of my stepfamily and that is a wonderful gift". Harriet has found a new partner who is content with her childless status. Felicity and her husband are the proud parents of an adopted boy.

But we shouldn't think that any of those five individuals have escaped suffering and all have had instances - some years after diagnosis - where their infertility has been a cause of distress. Maria suffered when her ex-husband remarried and started a family;
Jane when her brother and her best friend had children; Kate when she was accused of not understanding a mother's hurt because she herself was not a mother. Felicity has only just completed 5 years of individual therapy to come to terms with her experiences. Harriet still reports crying in the night.

It is clear that the shadows of childlessness are deep, long and lasting. And so my conclusion is once again as it was in the 2008 article: as health professionals, we should constantly be aware of the emotions experienced by women struggling with their fertility, and that we should offer all the support we can. This may still be hard for us to hear, but it is still necessary.

Acknowledgements The author would like to thank all the interviewees, especially Jackie Stewart, AMBICA counsellor.

Competing interests None declared.

Provenance and peer review Commissioned; internally peer reviewed.

\section{REFERENCES}

1 Quilliam S. Uncertain infertility: three women's experiences. J Fam Plann Reprod Health Care 2008;34:123-124.

2 Quilliam S. British Infertility Counselling Association. J Fam Plann Reprod Health Care 2015;41:154-155. 